\title{
KUALITAS PELAYANAN PEMBUATAN SERTIFIKAT TANAH PADA KANTOR PERTANAHAN / BADAN PERTANAHAN NASIONAL KOTA PALANGKA RAYA
}

\author{
Service Quality for Making Land Certificates at the Land Office I National Land Agency \\ of the City of Palangka Raya
}

\section{Raden Biroum \\ Bernardianto*}

Pipit Fitriyah

Universitas Muhammadiyah

Palangkaraya, Palangka Raya,

Central Kalimantan, Indonesia

email: a_biem@gmail.com

\section{Kata Kunci:}

Badan Pertanahan Nasional

Kualitas Pelayanan

Sertifikat Tanah

\section{Keywords:}

National Lad Agency

Service Quality

Land Certificates

\section{Accepted}

July 2018

Published

October 2018

\begin{abstract}
Abstrak
Selama ini masih banyak persepektif masyarakat bahwa untuk mengurus sertifikat tanah membutuhkan biaya yang mahal, waktu yang lama, prosedural yang rumit dan berbelit-belit dan penyelesaian pembuatan sertifikat tanah tidak tepat waktu masih belum sesuai dengan SOP sehingga hasilnya kurang optimal. Tujuan penelitian ini adalah untuk mengetahui kualitas pelayanan sertifikat tanah yang diberikan oleh pihak Badan Pertanahan Nasional (BPN) kepada masyarakat. Penelitian ini menggunakan jenis penelitian kualitatif. Berdasarkan hasil penelitian dapat dijelaskan bahwa Kantor Pertanahan/Badan Pertanahan Nasional Kota Palangka Raya dalam memberikan pelayanan sudah cukup memberikan kualitas pelyanan yang baik karena dilihat dari keseluruhan sudah baik walaupun masih ada saja masyarakat yang belum puas akan pelayanan petugas. Untuk mengetahui kualitas pelayanan penerbitan sertifikat tanah peulis menggunakan lima dimensi yaitu: tangible, reliability, responsiveness, assurance dan empathy. Disarankan dan diharapkan agar Pertanahan/Badan Pertanahan Nasional Kota Palangka Raya lebih meningkatkan kualitas pelayanan sertifikat tanah dan memprioritaskan perhatian terhadap perbaikan kualitas pelayanan pada ketepatan waktu pelayanan dimana petugas diharapkan untuk lebih tepat waktu dalam memulai kegiatan pelayanan. Serta ketepatan waktu penyelesaian pelayanan sertifikat tanah sesuai dengan SOP yang telah ada.
\end{abstract}

\begin{abstract}
So far there are still many community perspectives that to administer land certificates requires expensive, long time, complicated and convoluted procedures and the completion of land certificates that are not on time is still not in accordance with SOPs so the results are not optimal. The purpose of this study was to determine the quality of land certificate services provided by the National Land Agency (BPN) to the community. This study uses a type of qualitative research. Based on the results of the study, it can be explained that the Land Office / National Land Agency of the City of Palangka Raya in providing services is sufficient to provide good quality services because it is seen from the whole as good even though there are still people who are not satisfied with the services of officers. To find out the service quality of the issuance of the land certificate, the writer uses five dimensions, namely: tangible, reliability, responsiveness, assurance and empathy. It is recommended and expected that Palangka Raya City Land I National Land Agency will further improve the quality of land certificate services and prioritize attention to improving service quality on the timeliness of services where officers are expected to be more timely in starting service activities. As well as the timeliness of completion of land certificate services in accordance with existing SOPs.
\end{abstract}

\section{PENDAHULUAN}

Tanah pada dasarnya sangat dibutuhkan oleh makhluk hidup terutama manusia yaitu untuk kelangsungan hidupnya. Manusia tidak bisa terlepas dari tanah, karena dari setiap gerakan atau kegiatan sehari-hari manusia selalu berhubungan dengan tanah, baik untuk pertanian ataupun untuk pembangunan. Setiap jengkal tanah di mata hukum keagrariaan harus jelas status hak dan pemegang haknya.

Dengan demikian perlu adanya analisa mengenai prosedur yang diterapkan dalam memberikan pelayanan di Badan Pertanahan/Badan Pertanahan Nasional Kota Palangka Raya agar lebih berkualitas. Kasmir (2008) mengatakan bahwa pelayanan yang baik adalah kemampuan seseorang dalam memberikan pelayanan 
yang dapat memberikan kepuasan kepada pelanggan/publik dengan standar yang ditentukan. Namun berdasarkan pengamatan permasalahan peneliti seperti tingkat pelayanan kurang, pembuatan surat surat keterangan dan lainnya terlambat dan tidak tepat waktu, banyaknya tumpang tindih kepemilikan tanah atau lahan dan terkait petugas yang mengutamakan pelayanan terhadap orang yang menggunakan uang atau adanya relasi antara pemohon dengan petugas serta sarana pendukung dalam menunjang kegiatan dilapangan kurang dan prosedur atau mekanisme yang harus dilalui oleh para calon pemegang sertifikat tanah dari kantor pertanahan/Badan Pertanahan Nasional Kota Palangka Raya yang dianggap sulit dan berbelit - belit, khususnya pada pembuatan sertifikat tanah.

Adanya presepsi yang buruk tentang pegawai negeri sipil (PNS) harusnya menjadi kritikan keras bagi pemerintah. Upaya pemberdayaan PNS harus dilaksanakan dengan maksimal, karena pegawai merupakan pelaku dan penggerak mekanisme dalam sistem pemerintahan dan sebagai pelayanan publik. Di era globalisasi seperti saat ini tentunya pelayanan yang baik menjadi tolak ukur terhadap efektifitas dari kinerja pegawai di suatu kantor. Karena tercapainya tujuan suatu organisasi sangat berbanding lurus dengan kinerja pegawai yang ada pada kantor tersebut. Kinerja pegawai sangat selaras dengan mutu pelayanan kepada masyarakat, sehingga proses pelaksanaan kinerja yang kurang baik sangat mempengaruhi produk pelayanan yang dilakukan oleh pegawai terhadap masyarakat.

Menurut Laksana (2008) pelayanan berasal dari kata layan yang berarti menolong, membantu melayani. Sedangkan Moenir (200I) mengungkapkan bahwa pelayanan adalah proses pemenuhan kebutuhan melalui aktivitas orang lain secara langsung. Jadi dapat dikatakan bahwa pelayanan adalah merupakan serangkaian kegiatan guna memenuhi kebutuhan orang lain. Penekanan terhadap definisi pelayanan diatas adalah pelayanan yang diberikan menyangkut segala usaha yang dilakukan oleh seseorang dalam rangka mencapai tujuan guna untuk mendapatkan kepuasan dalam hal pemenuhan kebutuhan.

Menurut Sondang (2002:79) kualitas pelayanan adalah suatu bentuk penilaian konsumen terhadap tingkat layanan yang diterima dengan tingkat layanan yang diharapkan. Baik buruknya kualitas jasa tergantung pada kemampuan jasa dalam memenuhi harapan pemakainya. Semakin baik pemerintahan dan kualitas pelayanan yang diberikan maka semakin tinggi kepercayaan masyarakat. Penilaian kualitas pelayanan dibagi ke dalam lima dimensi. Kelima dimensi tersebut adalah:

I. Bukti Langsung (Tangibles) adalah dimensi yang berkenaan dengan daya tarik yaitu meliputi fasilitas fisik, perlengkapan pegawai, dan kondisi fasilitas penunjang, serta penampilan pegawai.

2. Keandalan (Reability) adalah dimensi yang berkenaan dengan kemampuan pegawai dalam memberikan layanan yang akurat sejak pertama kali tanpa 28 membuat kesalahan apapun dan menyampaikan jasanya sesuai dengan waktu yang disepakati.

3. Daya tanggap (Responsiveness) adalah dimensi yang berkenaan dengan kesediaan dan kemampuan para pegawai untuk membantu para pelanggan dan merespon permintaan mereka, serta menginformasikan kapan jasa akan diberikan dan kemudian memberikan jasa secara cepat.

4. Jaminan (Assurance) adalah dimensi yang berkenaan dengan perilaku para pegawai agar mampu menumbuhkan kepercayaan pelanggan terhadap pelayanan dan menciptakan rasa aman bagi para pelanggannya. Jaminan juga berarti bahwa para pegawai selalu bersikap sopan dan menguasai pengetahuan dan keterampilan yang dibutuhkan untuk menangani setiap pertanyaan atau masalah pelanggan.

5. Empati (Empathy) adalah dimensi yang berkenaan dengan pemahaman masalah para pelanggannya dan bertindak demi kepentingan pelanggan, serta 
memberikan perhatian personal kepada para pelanggan dan memiliki jam operasi yang nyaman. Kualitas pelayanan itu sendiri dapat diketahui dengan cara membandingkan persepsi para pelanggan atau konsumen atas layanan yang sesungguhnya mereka harapkan atau inginkan. Jika kenyataan lebih dari yang diharapkan, maka layanan dapat dikatakan bermutu.

\section{METODOLOGI}

Jenis Penelitian yang penulis pakai pada penelitian ini adalah jenis metode penelitian kualitatif. Dasar pemikiran yang membawa penulis menggunakan jenis metode ini adalah karena metode penelitian kualitatif sebagai metode yang tepat untuk menjelaskan, menggambarkan dan menafsirkan hasil penelitian dengan susunan kata dan atau kalimat sebagai jawaban atas permasalahan yang diteliti yaitu tentang Kualitas Pelayanan Penerbitan Sertifikat Tanah di Kantor Badan Pertanahan Nasional Kota Palangka Raya

\section{HASIL DAN PEMBAHASAN}

Berdasarkan yang penulis dapatkan dari hasil penelitian dari kualitas pelayanan di Kantor Pertanahan/Badan Pertanahan Nasional Kota Palangka Raya dalam melayani pemohon penerbitan sertifikat tanah dijelaskan sebagai berikut:

\section{Bukti Langsung (Tangibles)}

Terkait yang terwujud tentang yang berkenaan dengan daya tarik yaitu meliputi fasilitas fisik, perlengkapan pegawai, dan kondisi fasilitas dalam penunjang, serta penampilan pegawai Kantor Pertanahan/Badan Pertanahan Nasional Kota Palangkaraya terhadap kenyamanan pelayanan jasa untuk semua pemohon atau masyarakat Kota Palangka Raya. Bahwa keadaan yang terwujud dilihat dari segi fasilitas fisik yang terlihat di dalam kantor dan loket pelayanan sudah cukup baik dengan adanya komputerisasi maka informasi sertifikat tanah dengan mudah dapat dicek sampai dimana berkas yang diajukan pemohon sudah berjalan, dari perlengkapan pegawai cukup baik, dan dilihat dari segi penampilan petugasnya/pegawainya sudah sesuai prosedur yang ada hanya saja SDM yang masih kurang yang menyebabkan adanya petugas yang merangkap. Hal itu dikarenakan adanya fasilitas fisik yang sudah cukup memadai, perlengkapan dan kondisi fasilitas penunjang yang mendukung, serta penampilan fisik pegawai yang rapi dan sopan.

2. Keandalan (Realibility)

Kehandalan petugas disini yang berkenaan dengan kemampuan pegawai dalam memberikan layanan yang akurat dan tepat waktu. Harapan pemohon sertifikat tanah terhadap kualitas pelayanan di Kantor Pertanahan/Badan Pertanahan Nasional Kota Palangka Raya yang berkenaan dengan dimensi keandalan ini adalah meliputi kecepatan dalam memberikan pelayanan dan sifat dapat dipercaya. Dari hasil penelitian terungkap bahwa dilihat dari mengenai aspek kehandalan petugas belum baik, dikarenakan perkara kecepatan waktu yang lama dikeluhkan oleh masyarakat atau pemohon, dan adanya faktor internal yaitu ketidaklengkapan berkas dari pemohon, penundaan pembayaran yang harus dibayarkan, jarang adanya pengecekan dari pemohon mengenai perjalanan berkasnya masing-masing dan lain sebagainya maupun faktor eksternal yaitu gangguan sistem dari pusat yang menghambat kecepatan pelayanan dan penundaan pekerjaan atau penumpukan berkas yang terlalu lama.

3. Daya Tanggap (Responsiveness)

Terkait daya tanggap yang berkenaan dengan kesediaan dan kemampuan para pegawai di Kantor Pertanahan/Badan Pertanahan Nasional Kota Palangkaraya untuk membantu para pelanggan atau pemohon dan merespon permintaan mereka, serta menginformasikan kapan jasa akan diberikan dan 
kemudian memberikan jasa secara cepat kepada pelanggan/pemohon yang membutuhkan pelayanan sebagaimana diatur dalam perundangan yang berlaku. Berdasarkan hal tersebut diatas bahwa daya tanggap tentang kecepatan tanggapan yang dilakukan oleh pegawai atau petugas di Kantor Pertanahan/Badan Pertanahan Nasional Kota Palangka Raya belum cukup baik, karena dilihat dari segi masyarakat pengguna atau pemohon mereka masih banyak saja yang merasa petugas belum cukup baik merespon keluhan mereka (pemohon).

4. Jaminan (Asssurance)

Terkait Jaminan yaitu mencakup pengetahuan, kemam puan, kesopanan dan sifat dapat dipercaya yang dimiliki pegawai, bebas dari bahaya dan keraguraguan dan menciptakan rasa aman bagi para pelanggannya. Bahwa Jaminan terkait dengan jaminan ketepatan waktu pelayanan khususnya untuk ketepatan waktu jam kerja, petugas terkadang belum ada di tempat atau ruang pelayanan, seharusnya petugas lebih disiplin sesuai dengan aturan jam kerja mereka untuk kelancaran pelayanan juga. Selain itu jaminan ketepatan waktu untuk pembuatan sertifikat tanah juga dari pemohon masih kurang baik dikarenakan masih banyak yang tidak sesuai dengan Standar Operasional Prosedur, pemohon agak khawatir dengan tertundanya berkas yang semakin menumpuk dan lamanya penyelesaian pembuatan sertifikat tanah di Kantor Pertanahan/Badan Pertanahan Nasional Kota Palangka Raya. Namun terkait dengan jaminan legalitas masyarakat percaya karena berada dinaungan instansi pemerintah. Adapun Kepastian biaya petugas di Kantor Pertanahan/Badan Pertanahan Nasional Kota Palangkaraya telah menempelkan informasi terkait dengan biaya yang harus pemohon bayarkan. Dilihat dari sisi masyarakatnya bahwa pemohon tidak mempermasalahkan akan biaya yang memang sudah sesuai prosedur, apalagi dengan adanya program
Proyek Operasi Nasional Agraria (PRONA) sekarang, itu sangat membantu masyarakat terutama bagi golongan ekonomi lemah, karena dibebaskan dari kewajiban membayar uang pemasukan kepada Negara (tertera pada Kepmendagri No.189 Tahun 198I tentang Prona).

5. Empati (Emphaty)

Terkait Empati adalah yang berkenaan dengan pemahaman masalah para pelanggan nya dan bertindak demi kepentingan pelanggan, serta memberikan perhatian personal kepada para pelanggan termasuk juga kepekaan akan kebutuhan pemohon dan bersikap ramah kepada setiap pelanggannya. Dalam hal Empati sudah berjalan dengan cukup baik terbukti dengan sikap sopan dan keramahan serta kepedulian petugas kepada setiap pemohon layanan dengan mendahulukan kepentingan pemohon dalam melaksanakan tugasnya. Pemohon selalu mengharap kan sikap yang peduli tidak cuek, sopan dan ramah kepada setiap masyarakat pada semua instansi pemerintah sebagai pelayan publik karena hal ini sangat penting untuk kenyamanan masyarakat melakukan pelayanan.

\section{KESIMPULAN}

Berdasarkan hasil penelitian yang dilakukan di Kantor Pertanahan/Badan Pertanahan Kota Palangkaraya, dapat disimpulkan beberapa hal mengenai Kualitas Pelayanan Penerbitan Sertifikat Tanah pada Kantor Pertanahan/Badan Pertanahan Kota Palangkaraya. Diantaranya adalah fasilitas yaitu sarana dan prasarana yang ada di Kantor Pertanahan/Badan Pertanahan Nasional Kota Palangka Raya terhadap kualitas pelayanan dengan dimensi Bukti Langsung pada dasarnya sudah baik. Kualitas pelayanan pembuatan sertifikat tanah pada Kantor Pertanahan /Badan Pertanahan Nasional Kota Palangka Raya dengan dimensi Keandalan belum baik. Untuk Kualitas pelayanan pembuatan sertifikat tanah pada Kantor Pertanahan/Badan 
Pertanahan Nasional Kota Palangka Raya dengan dimensi Daya Tanggap masih belum baik. Untuk Tingkat pelayanan pembuatan sertifikat tanah pada Kantor Pertanahan/Badan Pertanahan Nasional Kota Palangka Raya dengan dimensi Jaminan sudah baik. Sementara Kualitas pelayanan pembuatan sertifikat tanah pada Kantor Pertanahan/Badan Pertanahan Nasional Kota Palangkaraya dengan dimensi Empati sudah baik.

\section{REFERENSI}

Kasmir. 2008. Etika Costumer Service. Jakarta: Raja Gravindo Persada.

Laksana. 2008. Manajemen Pemasaran Pendekatan Praktis.Yogyakarta: Graha IImu.

Moenir, H.A.S. 2002. Manajemen Pelayanan Umum di Indonesia. Jakarta: Bumi Aksara.

Siagian, S.P. 2002. Kepemimpinan Organisasi \& Perilaku Administrasi. Jakarta: Gunung Agung.

Sugiyono. 2014. Metode Penelitian Administrasi. Bandung: Alfabeta

Tjiptono, F. \& Chandra, G. 2005. Service, Quality And Satisfaction. Yogyakarta: Andi Offset.

Tjiptono, F. \& Diana. 2003. Total Quality Management. Yogyakarta: Andi Offset.

Wibowo. 20I4. Manajemen Kinerja. Depok: Rajagrafindo Persada. 